\title{
A BRIEF HISTORICAL BACKGROUND OF THE ARMENIANS AND MONGOLS
}

Before moving on to the relationship set up between the Mongols and the Armenians, it is necessary to give a short historical background about the origin, location and history of them. It is especially important to mention the historical conditions of the Armenians on the eve of the Mongol conquest, when Greater Armenia and Cilician Armenia existed separately from each other with no major political contacts, although with constant cultural, religious and trading links. The Mongols were dealing with two different vassal states, of which the Greater Armenians were their subjects, while the Cilician Armenians were their allies.

\section{The Armenians in Greater Armenia}

The history of the Armenian people goes back to Hittite and Assyrian times and it has formed a part of the history of the north-eastern region of the Mediterranean world, existing and being influenced by Aegean-Anatolian, Mesopotamian, Iranian, Hellenistic and RomanoByzantine civilisations. ${ }^{1}$ A description of earlier Armenian geography is given by Strabo (63/64 BC-24 AD), the Greek geographer and historian. ${ }^{2}$ The historical Armenian plateau is the highest among the three land-locked plateaus that form the northern part of the Middle East. In the west, it borders with the Anatolian plateau, and in the south-east with the Iranian plateau. ${ }^{3}$ Mount Ararat (Masis) is about 17,000 feet (about 5,200m) above sea level and represents the highest point not only in Armenia, but also in West Asia. The southern frontiers of Armenia reach the lowland steppes of Syria and Mesopotamia; to the north, they extend to the trench plains of South Caucasia (Georgia and Azerbaijan) backed by the great wall of the

\footnotetext{
1 Toumanoff, 1966:593; Redgate, 2000:2-6, 18-24.

2 Strabo, XI, xiv, 1969:317-341. On the geography of Armenia according to Strabo, see Syme, 1995:27-83.

3 The subsequent description of Armenia follows Hewsen, 1997:1-17.
} 
Caucasus mountain range which stretches between the Caspian and Black Seas. Hewsen notes that the natural frontiers of the Armenian plateau are clearly defined in the east, the north-west and the south, while the borders in the west, the south-east and the north are obscure. ${ }^{4}$ This point enables us to make an assumption that the people inhabiting those frontier areas would have had reasons not only to mingle with each other, but also to fight for possession and control of these lands.

Scholars' views differ on the origin of the Armenian people. Some agree that the Armenians were not the original inhabitants of the plateau. ${ }^{5}$ The predominant view is related to the migration of people, particularly the Indo-European Hittites, to Transcaucasia and Asia Minor at the beginning of the second millennium BC. According to some historical and archaeological studies, they migrated into the Armenian plateau, forming a federation of people known as the Armens. This version of the Armenians' origin is suggested by Russell, who through linguistic research into the other inhabitants of the Armenian plateau, such as the Phrygians, Persians, Babylonians, etc., proposes that the people who moved from far south-eastern Europe into Anatolia became the Armenians. ${ }^{6}$ However, according to another hypothesis, which suggests no mass migration, it is considered that the proto-Armenians were the native inhabitants of this territory situated on the highlands of the Anatolian plateau between the Black and the Caspian Seas. This recent account of the Armenians' origin, though having its supporters, has not gained wide approval. ${ }^{7}$ However, the common outcome of both hypotheses is that by the development of bronze in the Middle East, the Armenian people ended up inhabiting the region around the Biblical Mount Ararat. ${ }^{8}$

From the middle of the second millennium $\mathrm{BC}$ to the thirteenth century $\mathrm{AD}$, the Armenian plateau lay at the crossroads of rival

${ }^{4}$ Hewsen, 1997:2.

${ }^{5}$ Ibid., 2.

${ }^{6}$ Russell, 1997:19-24.

7 Ibid., 24.

${ }^{8}$ Mount Ararat, towering over the great river valleys of Araxes (Armenia), Lake Van (in present day Turkey) and Lake Urumiah (in present day Iran) has the status of a holy site to the Armenians. One of the six major Armenian rivers, the Araxes, watering the vast Ararat plain and passing through many of the great cities of Armenian antiquity, has played a considerable part in the national life of the Armenians. It is the only true river of modern Armenia and it has become, like Mount Ararat, a national symbol to the Armenian people. 
empires: Assyrian, Median, Achaemenid, Parthian, Sasanian, Arab, Seljuk and Mongol to the south and east, and Seleucid, Roman, Byzantine and Crusader to the west.

The migration of Turks to Asia Minor that occurred between the eleventh and fifteenth centuries also directly involved a change in the policy, demography and economy of the Armenian people who populated vast areas across that region. From $c a .1016$ onwards, most of the Armenian highlands underwent several invasions of various Turkic speaking people from different regimes. ${ }^{9}$

The growing Georgian military power in the late eleventh century established temporary supremacy in eastern Asia Minor. Georgia was transformed into a powerful pan-Caucasian empire. ${ }^{10}$ (see Map 1). During the reign of David the Builder (1089-1125), the Armenian territories of Lorí, Agarak, the Kiurikian holdings, eastern Gugark, western Utik, Gag, Kavazin, Kayan, Terunakan, Norberd, Tavush and many others were freed of nomadic Turkomans by the Georgian army from 1110-1123. ${ }^{11}$ Ani was taken in $1123 .{ }^{12}$ Several noble Armenian families, joining the Georgian army, participated in the liberation of their country from the Turks. ${ }^{13}$ During the reigns of Demetrē I (1125-1155) and Georgi III (1156-1184), the Georgian conquest continued, when the Armenian lords of the Zak arian (Mkhrgrtseli), Orbelian (Orbeli), and Artsruni (Mankaberdeli) were brought within the ruling structure of the country. When the Georgian Bagratids achieved their apogee under Queen Tamar (1184-1213), the Armenian Zak'arid brothers Zak'arē and Iwanē were appointed as the commanders of the Armeno-Georgian armies. ${ }^{14}$

In the first decades of the thirteenth century, north-eastern Armenia was under the rule of the Zak'arid family. The land was received by the Zak arids as the reward from the Georgian crown for their military service. ${ }^{15}$ Although the Zak arids paid tributes to the Georgian court, Armenian economic and cultural life reached new heights. ${ }^{16}$ The lands of Lori, Ani, Aragatsotn, Bagrewand, Tsaghkotn, Kogovit, Surmari and other north-western territories were under the

\footnotetext{
9 Cahen, 1968:27, 32-50.

10 Toumanoff, 1966:623.

11 Babayan, 1976:525.

12 Bedrosian, 1997:251.

13 Ibid., 88.

14 Step'annos Orbelian, 1910:391-392; Kirakos Gandzakets i, 1961:162-163.

15 Babayan, 1976:541-542.

16 Bedrosian, 1997:253, 255.
} 
jurisdiction of the amirspasalar (commander-in-chief) Zak'arē and his son Shahnshah. Subject to the Zak'arid House were the families of the Vachutians, Pahlavunis, Mamikoneans, Artsrunids and others. ${ }^{17}$

The eastern areas Bjni, Geghark'unik', Vayots'-Dzor, most of Artsakh, Siwnik', Nakhichevan, Dwin and Erevan were under the jurisdiction of the atabeg (atabek) Iwanē Zak'arian and his son Awag. First Dwin and later Bjni were centres of this division. The subjects of Iwanē's family were the Orbelians, Khaghbakians, Dopians, HasanJalalians and others (see Map 4). ${ }^{18}$ The representatives of these major Armenian families entered into direct contact with the Mongols in order to retain their conquered lands, the discussion of which follows in next chapters.

\section{The Armenians in Cilician Armenia}

In the history of the Armenian people, the Cilician period is defined principally through the actions of two Armenian families, the Rubenids and the Het umids; ${ }^{19}$ by the political union with Byzantium and the Catholic Church; and by the involvement in the Frankish Crusades.

Geographically, the area was surrounded by three mountain ranges: the Taurus Mountains, the Anti-Taurus Mountains and the Amanus Mountains (see Map 2). ${ }^{20}$ Topographically, it consisted of two distinctive regions: The one, Cilicia Pedias, a fertile plain bounded by the Taurus and Anti-Taurus Mountains and the Mediterranean Sea, and the other, Cilicia Tracheia, a stony, rugged region that stretched to the west. The Taurus Mountains, reaching heights of about 11,500 feet $(3,500 \mathrm{~m})$ separated Cilicia from Cappadocia and were a natural means of defending the land from the north and the west. In particular, the mountains protected the land from neighbouring countries, and the main entry from the Taurus Mountains was by the Cilician Gates, a long and narrow pass leading to the city of Tarsus. Through this Gate, Alexander the Great, as well as the

\footnotetext{
17 Babayan, 1976:543.

18 Step'annos Orbelian, 1910:397; Babayan, 1976:546-550.

19 On the Pahlawunis (ca. 1071-ca. 1149), see Dédéyan, 1996:169-173.

20 The geographical description of the terrain follows Mikaelean, 1952:5-14.
} 
Crusaders, entered Asia Minor. ${ }^{21}$ Abū al-Fidā', an Arabic geographer, writing in the fourteenth century, comments that the kingdom of Little [Cilician] Armenia is called the Bilād Sìs, the northern frontier of which stretches from Balis besides the Euphrates to Tarsus and the Mediterranean Sea. ${ }^{22}$ Access to the Mediterranean Sea in the south was the potential advantage of this location.

In medieval European historiography, this land was called Ermenie, Armenia or Lesser Armenia, causing some confusion in the naming of different states of Armenia. ${ }^{23}$ In order to differentiate Cilicia of the eleventh to fourteenth centuries from Lesser Armenia, which existed from the first century BC to the south and south-west of Pontus, modern historians refer to Cilicia as the Armenian Kingdom of Cilicia. In this work, Cilician Armenia stands for the territory of the Armenian Principality (1080-1199) and the Armenian Kingdom of Cilicia (1199-1375; see Map 2). Contemporary Armenian historians referred to Cilicia (Kilikia) also as Ashkharh Kilikioy (Cilician Land), or Ashkharh Kiliketswots (Land of the Cilicians) ${ }^{24}$ or Koghmank'Kiliketswots (Country of Cilicians). ${ }^{25}$

Over the centuries, Greeks, Arabs and Jews populated the region. The Byzantine Emperor Justinian II (685-695), due to the threat from the rapid spread of Islam and as a measure of defence against it, started to implement a policy of relocation of the native population and their mass transfer deeper into the empire. ${ }^{26}$

Among the earliest Armenian settlers in Lambron (Cilicia) was Oshin from the House of Het'um, as well as Baron Gogh Vasil (Basil the Robber) and many other noblemen. ${ }^{27}$ When the Seljuk Sultan

21 Mikaelean, 1952:11.

22 Abu-l Fidā, quoted in Le Strange, 1890:27.

$23 \mathrm{RHC} / \mathrm{DA}, 1869$. The term Lesser Armenia has denoted either Armenia Minor since the third century BC or the provinces of Armenia west of Euphrates, which, after the administrative reorganisations of the Roman Emperor Justinian I (527-565), were named as Armenia I and Armenia II (see Hewsen, 2001, 1997:1-17.

24 Smbat Sparapet, 1869:610, 667.

25 Kirakos Gandzakets'i, 1961:27, 354.

26 Byzantine policy encouraged the emigration of the Armenians from their main lands to the western part of the Euphrates. This flow continued during the Arab invasion (from the seventh to the ninth centuries) as well as the Seljukid incursion (eleventh century), when the repressive taxes levied by new governors caused massive Armenian immigration into Cilicia (Der Nersessian, 1962:631).

27 The Armenian lieutenant Gogh Vasil inherited Raban and Kesun upon the death of Philaretus in 1092. He also held Hromklay for a time (Der Nersessian, 1962:632). 
Alp Arslan defeated the Byzantine emperor in the battle of Manzikert in 1071, the Armenians, especially the chieftains, came to hold the strategic fortresses and, consequently, positions of dominance in Cilicia. ${ }^{28}$ In other words, an Armenian Principality emerged in this territory, which was under the control of the two main Armenian families already mentioned, the Rubenids and the Het'umids. The conflict between two princely families over each others' territories troubled the Catholicos Gregory III (1113-1166), who, after his failure to reunite them, sought refuge in Hromklay (Qal'at ar-Rūm) where later, in 1151, the See of the Cilician Armenian Catholicos was transferred. ${ }^{29}$

On the eve of the Mongol conquest, the prosperous and powerful reign of Lewon II (1187-1219), known as King Leon (Leo I) the Magnificent (r. 1199-1219) ${ }^{30}$ promoted the economic development of Cilicia through several trade routes: Syria-Konya-Constantinople; Tabriz-Marash-the Mediterranean; and the Persian Gulf-SyriaCilicia, which converged towards the Cilician ports of Ayas (Lajazzo), Korikos and Tarsus. ${ }^{31}$

His reign was continued by the joint rule of his daughter Zabel (Isabel) and Het'um I (1226-1269), the son of Kostandin of Lambron, finally bringing the two contending Rubenid and Het'umid families into an alliance. ${ }^{32}$ The period of Het'um's rule marked a golden age in Cilician Armenia. He strengthened the Armenians' ties with the Frankish states, especially with the Kingdom of Cyprus and the Principality of Antioch through family marriages. ${ }^{33}$ Nevertheless, peace was relative. Het'um faced problems on his eastern frontiers. The Mongol expedition approached Asia Minor.

28 Bournoutian, 1997:276.

${ }^{29}$ Hromklay was offered to Gregory by Beatrice, the wife of Joscelin II, Count of Edessa / Courtenay (d. 1159), who was imprisoned by the Turks. Later, Gregory purchased it from his son, Joscelin III (1159- 1200) for 15,000 dahekans (Der Nersessian, 1973(I):338.

${ }^{30}$ Der Nersessian, 1973(I):340.

31 Toumanoff, 1966:633.

${ }^{32}$ Zabel, Queen of Armenia (1219-1252), Lewon's daughter from his second marriage to Sybille Lusignan of Cyprus.

33 Burger, 1988:xvi. 


\section{The Mongols}

According to archaeological discoveries, the vast steppes of the Mongolian plateau have been populated since 800,000 BC. ${ }^{34}$ The Mongol, Turkic and Tungusic pastoral tribes made this plateau their homeland, which lay between the northern edge of the Tien Shan and the southern end of the Altai Mountain range. The Mongolian plateau is divided into taiga forest in the north, steppes and river valleys, which stretch from west to east, and the desert area in the south. The excessive heat of the Gobi desert in summer and the bitter wind from Siberia in winter made the Mongol tribes settle and master the steppes or the grassy plains that were located between the mountain ranges, where the Onon, Orkhon, Tuul and Kherulen rivers flowed. The development of herding in Mongolia dates from 2000 $\mathrm{BC}$, long before the construction of the Great Wall in China (ca. 209 $\mathrm{BC})$ that was used to protect the Chinese border from the nomadic peoples that swept across the region..$^{35}$

From ancient times, various peoples have inhabited the territory of modern Mongolia, before or besides the Mongols proper. The earliest kingdoms were the Xiongnu (Hsiung-nu /Hun /Hunnu) (209 BC-93 AD), ${ }^{36}$ the Xianbis (Hsien-pi) (the first to the third centuries), ${ }^{37}$ the Jujan or Juan-Juan Empire (the fourth and fifth centuries) and the Turkic Khanate (the sixth to the seventh centuries) with its centre in the Orkhon valley. ${ }^{38}$ In 745 , the Turkic Khanate was replaced by the Uighurs. The capital of the Uighur Khanate was Qara-Balgasun or Ordu Baliq on the right bank of the Orkhon River. Uighur Khan Peilo (d. 756) and his heir Moyun-Chur (746-759) sat on the throne in 747 and succeeded in expanding his territories from the Altai Mountains in the west to the Khingans in the east, from the Gobi in

34 Tseveendorj, 2003:57-66.

35 Barfield, 1989:20-24, 28-30.

36 On Huns, see Maenchen-Helfen, 1973; Thompson, 1996. Much later, when the northern branch of Huns broke into four groups, the very last remnants of Huns travelled to the far west and became known to Europeans. Their notorious leader Attila (AD 406-453) caused terror in Europe and created an ephemeral state in Central Europe, which collapsed after his death (Shirendyb, 1966:82).

37 While Xianbis absorbed some Huns, the southern Huns moved to China and Central Asia (Shirendyb, 1966:82). More on steppe pastoralism and the interactions of steppe empires with neighbouring Chinese dynasties in late BC and early AD in Barfield, 1989:20-24, 32-45, 85-101, 120-127.

38 Shirendyb, 1966:88. On early steppe Empires and their relations with China, see Barfield, 1989:20-97, 120-127. 
the south to the Sayan Mountains in the north. ${ }^{39}$ The economy of the Uighurs was based on animal husbandry, hunting as well as agriculture, since some of them practised a sedentary lifestyle. Those who were settled were also engaged in the construction of buildings. ${ }^{40}$ The outstanding achievement of both the Uighurs and the Mongols was the adoption of a script based on the Sogdian alphabet, which was derived from Aramaic. ${ }^{41}$ Although the Uighurs were Buddhists, through the transmission of Sogdian culture, Manichaeism was declared the state religion in 763. At the end of the tenth century, Nestorian Christianity entered Uighuria. Nevertheless, the majority of the Uighurs practised Shamanism. ${ }^{42}$ In 840, the Yenisei Kyrgyz tribes took the Uighur capital and expelled the native population. Some of the Uighurs fled to Western Turkestan and Dzungaria, some were absorbed by the Kyrkyzs, while others fled to Manchuria. ${ }^{43}$

The empires of Kyrgyzs (in the ninth century) and Kidans (Khitans, during the tenth and eleventh centuries) were the masters of the steppe until their role passed to many other Turkic and Mongol pastoral tribes of the Mongolian plateau of the twelfth century. Among these tribes the Naimans, Keraits, Merkits and Tatars were the most powerful. Mention must be made of the Oirats, Taiji'uts, Onggirats, Jalayirs, Onguts, Besuts and many others who were amalgamated into the Yeke Monggol Ulus (the Great Mongol State) in 1206. The man who led this nation to victory was Temüjin (Temuchin) of the Borjigin obogh (clan, tribe), better known by the title Chinggis Khan (r. 1206-1227). ${ }^{44}$ The representatives of these tribes made a great impact on the history of the Mongols and the Mongol Empire and for that reason, where it is possible, I give the tribes' names along with the names of the Mongols stated in this work.

39 Shirendyb, 1966:92-93.

40 Ibid., 94; Morgan, 1990:44-48.

${ }^{41}$ Before the invention of the Uighur script, the Uighurs used the Orkhon script (Shirendyb, 1966:95).

${ }_{42}$ Okladnikov, 1983:116.

${ }^{43}$ Shirendyb, 1966:93.

${ }^{44}$ Temüjin means the smith and the most popular explanation for his title as Chinggis Khan is that it stands for the Oceanic Khan or Universal Ruler. Another explanation for this name is that it derives from the Mongolian word 'chinga' (strong, solid, powerful) to mean unbeatable and firm (cf. Tsevel, 1966:823; Lessing, 1973:189). The etymology and meaning of Chinggis is still a subject of dispute. For the various explanations of Chinggis, see De Rachewiltz, 1989:281-298. 
With the assistance of his relatives and friends, Chinggis Khan was able to build up a disciplined army that expanded a steppe confederation into a world empire. The great achievement of Chinggis Khan in uniting the Mongol steppe tribes under one rule was dictated by his instinctive sense of survival, in terms of both politics and economics. For the most part, the union was the result of the emerging need to develop a nomadic infrastructure throughout the Inner Asian plateau. In addition, there was a power vacuum in most lands conquered by the Mongols. China was disunited and relatively weak due to the internecine strife between the Chin (Jin) and Sung dynasties. ${ }^{45}$ Central Asia was fragmented into several khanates and citystates. In the Middle East, the 'Abbasid dynasty that had ruled from Baghdad for five centuries was in decline. Russia was also disunited and fragmented. All of these areas suffered from a lack of centralised control, which was exploited by the Mongols.

The Yeke Monggol Ulus was the largest contiguous land empire at its apogee in the mid-thirteenth century (see Map 3). After Chinggis Khan's death in 1227, the conquered territories were ruled by his sons, by his senior wife Börte and by his grandsons. These territories later became autonomous separate Mongol Uluses (States). The Ulus of Jochi (1237-1357), later known as the Golden Horde (Altan Ordyn Ulus) or Qipchak Khanate (1243-1502) was the inheritance of Chinggis Khan's eldest son Jochi and grandson Batu. It included at its peak most of European Russia from the Urals to the Carpathian Mountains, with its southern borders on the Black Sea and its key base in the Pontic and Caspian steppe and its capital at Sarai. ${ }^{46}$ The Chaghatai Ulus or Chaghatai Khanate (1224-1678) formed the inherited territories of the second son of Chinggis Khan, Chaghatai, who controlled Transoxiana or most of what is now Central Asia. The Il-Khanate (1256-1353) that included Iran, Iraq, Afghanistan, Asia Minor and the Caucasus was ruled by the offspring of Tolui Khan, the youngest son of Chinggis. The Toluid Qubilai (Kublai) Khan (1260-1294) declared Mongol rule in China in 1271, which became known as the Yüan Empire or the Yüan Dynasty that lasted until

${ }^{45}$ Morgan, 1990:50-51.

46 In the Quriltai (Great Assembly) of 1235, it was decided to launch an expedition to Russia and Eastern Europe. In 1236, Batu started his conquest of Russia. The Golden Horde ruled over Russia from 1243 to 1480. 
1368 and expanded into Korea, Japan, Myanmar (Burma), Vietnam and Java (Indonesia). ${ }^{47}$

According to Morgan, 'the major difference between the Mongols and previous conquerors is that no other nomadic empire had succeeded in holding both the Inner Asian steppe and the neighbouring sedentary lands simultaneously. ${ }^{3} 8$ It is always challenging to understand how the Mongols were able to establish the largest land empire in world history with a population of about two million, ${ }^{49}$ when China alone had a population of a hundred million. ${ }^{50}$

The Mongols' intention to create a world empire was driven by their successful campaigns for expansion. ${ }^{51}$ Ratchnevsky, analysing Chinggis Khan's actions, indicates that there were prevailing political and military reasons. ${ }^{52}$ Scholars agree that each of Chinggis Khan's decrees to launch expeditions was based on specific circumstances, such as the assault on his diplomatic missions, trade disputes or the breakdown of agreements. ${ }^{53}$ Nevertheless, Chinggis Khan was vengeful, taking revenge on the Taiji'uts, the Tatars and the Tangquts. ${ }^{54}$ Verbal insults against the Mongols by Gürbesü, the Queen of the Naimans, were avenged. ${ }^{55}$ However, Chinggis Khan and his descendants launched attacks only after giving full warning of their intention. ${ }^{56}$ Mongol war techniques and tactics were surely connected to military organisation, and scholars agree that during sieges, the Mongols mastered the art of raiding independently several surrounding cities and places so that the rumours of terror would shock the entire population; this was true of Mongol tactics in Greater Armenia

${ }^{47}$ Qubilai's election in May 1260 was contested by his brother Arïgh Böke, who was proclaimed the Great Khan in June 1260 (Rossabi, 1988:53, 136).

${ }^{48}$ Morgan, 1986:5.

49 Saishiyal, 1987(I):564-565. During the time of Chinggis Khan, the population of the eastern steppe, modern Mongolia, was somewhere between 700,000 and 1,000,000 (Allsen, 2001:5).

${ }^{50}$ The population of China in the Sung and Chin periods was over 100 million (Langlois, 1981:20). No steppe power had ever fought against Chinese dynasties so persistently, like the Mongols (Barfield, 1989:198).

${ }^{51}$ Ratchnevsky, 1991:160.

52 Ibid., 121.

53 Allsen, 2001:17; Ratchnevsky, 1991:170;

${ }^{54}$ MNT, 2004:37(\$148-149), 39(\$153-154), 84(\$249).

${ }_{55}$ Ibid., 54(\$189).

${ }^{56}$ Ratchnevsky, 1991:129-130. 
as well. Chinggis Khan used terror as a strategic weapon. Purposeful terror with fewer losses was as useful as siege-craft. ${ }^{57}$

Chinggis Khan, who, according to Fletcher, after reaching a certain level of power, deviated from the 'supratribal' ruler, ${ }^{58}$ established the institution of loyalty through three important ties: anda, the tie of sworn brotherhood; khuda (quda), the tie of marriage; and nöker, the tie of friendship. ${ }^{59}$ This institution proved itself and worked as a basic concept to recruit people when he needed reliable support. Organising a military decimal system, where the units were divided into tens, hundreds and thousands, increasing up to ten thousands (tümens), Chinggis Khan broke the patriarchal tribal clan (obog) network, intermixing the tribes under 95 elite commanders. ${ }^{60}$ These commanders were appointed from different social strata: tribal chiefs, humble herdsmen and even vassal members. The most faithful followers and nökers (friends) formed the kheshig (kesig), ${ }^{61}$ the imperial guard, recruited from across tribal boundaries, which became a 'nursery of the new Empire's ruling class.'62

When Chinggis Khan set up the administration of his Empire, it bordered with the Chin Empire to the southeast, the Tangqut kingdom of Hsi-Hsia to the south-west and the kingdom of Qara-Khitai (Liao) to the west. ${ }^{63}$ These neighbours sought to destroy this newlyemerged kingdom, while it was still weak, so Chinggis decided to launch a pre-emptive strike. The weakest of them was the kingdom of Hsi-Hsia, and it was the first to experience Mongol attacks. The invasion of the Chin Empire followed. Learning that Western Liao planned to attack him, Chinggis Khan turned his attention to QaraKhitai in $1218 .^{64}$

This expansion brought the Mongols into direct contact with the territory of the Khwārazm-Shāh, Qara-Khitai's western neighbour. Embassies were exchanged between the two rulers. In the same year,

\footnotetext{
57 Ratchnevsky, 1991:160; Hildinger, 1997:128.

58 Fletcher, 1986:20.

59 MNT, 2004:17(\$92-93), 21(\$105), 26(\$118), 45-46(\$170-171), 78-79(\$238), 66(\$203).

60 Ibid., $74-75(\$ 220-225)$.

61 Ibid., 55(\$191), 75(\$226). On Kheshig in Iran, see Melville, 2006a:135-163.

62 Morgan, 1986:90.

63 The Chin Empire was located in northern China, with its capital at Peking (Beijing); the Kingdom of Tangqut lay in the upper reaches of the Yellow River, ruled by a people of Tibetan origin.

64 MNT, 2004:85-86(\$250-253).
} 
1218, a great caravan of Muslim merchants with about 500 camels loaded with gold, silver, Chinese silk, sables and other goods was sent to Khwārazm-Shāh by Chinggis Khan. Accompanying them were several Mongols sent on a special mission to the Khwārazm-Shāh's court. The local governor of Utrār, the border city in Kh"ārazmian territory, massacred the travellers, which was the direct cause of the Mongols' advance into Central Asia and further into the Middle East. ${ }^{65}$ The Mongols penetrated Transoxiana, Afghanistan and Khurasan. The Mongol generals Sübedei and Jebe then pursued the $\mathrm{Kh}^{\text {warazm}-S h a ̄ h ~ w e s t w a r d s, ~ b r i n g i n g ~ t h e ~ M o n g o l s ~ t o ~ A r m e n i a ~ i n ~}$ 1220.

${ }^{65}$ Barthold, 1977:397-398. 